\title{
Turn Left for Sustainable Growth
}

JOSEPH E. STIGLITZ

$\mathrm{B}$ oth the left and the right say they stand for economic growth. So should voters trying to decide between the two simply look at it as a matter of choosing alternative management teams?

If only matters were so easy! Part of the problem concerns the role of luck. America's economy was blessed in the 1990s with low energy prices, a high pace of innovation, and a China increasingly offering high-quality goods at decreasing prices, all of which combined to produce low inflation and rapid growth.

President Clinton and then-Chairman of the US Federal Reserve Alan Greenspan deserve little

Joseph E. Stiglitz, Professor at Columbia University, received the 2001 Nobel Prize in economics. He is the co-author, with Linda Bilmes, of The Three Trillion Dollar War: The True Costs of the Iraq Conflict. credit for this—-though, to be sure, bad policies could have messed things up. By contrast, the problems faced today-high energy and food prices and a crumbling financial system-have, to a large extent, been brought about by bad policies.

There are, indeed, big differences in growth strategies, which make different outcomes highly likely. The first difference concerns how growth itself is conceived. Growth is not just a matter of increasing GDP. It must be sustainable: growth based on environmental degradation, a debtfinanced consumption binge, or the exploitation of scarce natural resources, without reinvesting the proceeds, is not sustainable.

Growth also must be inclusive; at least a majority of citizens must benefit. Trickle-down economics does not work: an increase in GDP can actually leave most citizens worse off.

๑ The Berkeley Ele Głronightressyou by | Columbia University Law Library New York (Columbia University Law Library New York)

America's recent growth was neither economically sustainable nor inclusive. Most Americans are worse off today than they were seven years ago.

But there need not be a trade-off between inequality and growth. Governments can enhance growth by increasing inclusiveness. A country's most valuable resource is its people. So it is essential to ensure that everyone can live up to their potential, which requires educational opportunities for all.

A modern economy also requires risk-taking. Individuals are more willing to take risks if there is a good safety net. If not, citizens may demand protection from foreign competition. Social protection is more efficient than protectionism.

Failures to promote social solidarity can have other costs, not the least of which are the social and private expenditures required to

Economists' Voice September, 2008 
protect property and incarcerate criminals. It is estimated that within a few years, America will have more people working in the security business than in education. A year in prison can cost more than a year at Harvard. The cost of incarcerating two million Americans-one of the highest per capita rates in the world-should be viewed as a subtraction from GDP, yet it is added on.

A second major difference between left and right concerns the role of the state in promoting development. The left understands that the government's role in providing infrastructure and education, developing technology, and even acting as an entrepreneur is vital. Government laid the foundations of the Internet and the modern biotechnology revolutions. In the nineteenth century, research at America's government-supported universities provided the basis for the agricultural revolution. Government then brought these advances to millions of American farmers. Small business loans have been pivotal in creating not only new businesses, but whole new industries.

The final difference may seem odd: the left now understands markets, and the role that they can and should play in the economy. The right, especially in America, does not. The New Right, typified by the Bush-Cheney administration, is really old corporatism in a new guise.

These are not libertarians. They believe in a strong state with robust executive powers, but one used in defense of established interests, with little attention to market principles. The list of examples is long, but it includes subsidies to large corporate farms, tariffs to protect the steel industry, and, most recently, the megabail-outs of Bear Stearns, Fannie Mae, and Freddie Mac. But the inconsistency between rhetoric and reality is long-standing: protectionism expanded under Reagan, including through the imposition of so-called voluntary export restraints on Japanese cars.

By contrast, the new left is trying to make markets work. Unfettered markets do not operate well on their own-a conclusion reinforced by the current financial debacle. Defenders of markets sometimes admit that they do fail, even disastrously, but they claim that markets are "self-correcting." During the Great Depression, similar arguments were heard: government need not do anything, because markets would restore the economy to full employment in the long run. But, as John
Maynard Keynes famously put it, in the long run we are all dead.

Markets are not self-correcting in the relevant time frame. No government can sit idly by as a country goes into recession or depression, even when caused by the excessive greed of bankers or misjudgment of risks by security markets and rating agencies. But if governments are going to pay the economy's hospital bills, they must act to make it less likely that hospitalization will be needed. The right's deregulation mantra was simply wrong, and we are now paying the price. And the price tag-in terms of lost output-will be high, perhaps more than $\$ 1.5$ trillion in the United States alone.

The right often traces its intellectual parentage to Adam Smith, but while Smith recognized the power of markets, he also recognized their limits. Even in his era, businesses found that they could increase profits more easily by conspiring to raise prices than by producing innovative products more efficiently. There is a need for strong anti-trust laws.

It is easy to host a party. For the moment, everyone can feel good. Promoting sustainable 
growth is much harder. Today, in contrast to the right, the left has a coherent agenda, one that offers not only higher growth, but also social justice. For voters, the choice should be easy.

Letters commenting on this piece or others may be submitted at submit. cgi? context=ev. 